\title{
Current development of tourism and recreation on Baltic Sea coasts: new directions and perspectives
} Lemenkova Polina*

*PhD Student, Charles University in Prague, Faculty of Science, Institute for Environmental Studies (Univerzita Karlova v Praze, Př́rodovědecká fakulta). Benátská 2, 12843 Praha 2, Czech Republic.

\begin{abstract}
Research work analyzes current situation and development of tourism in the region of Baltic Sea. Specific case study of this paper is Pärnu Bay, Estonia. This region is known for unique environmental settings: mild maritime climate, broad beaches, coniferous pine forests on the coastal zone and high esthetic value of the surrounding landscapes. However, after the end of USSR, Estonia survived a difficult period of re-structuring of economic and social system. This affected touristic cluster, rapidly developing in new directions. Soviet touristic areas became abandoned and re-constructed, new hotels are being actively created, intensive privatization of recreation houses is actively ongoing. Main problem in the touristic cluster in Estonia consists in its specific location on the Baltic Sea with cold climate in summer period. It causes low popularity among tourists, comparing to Mediterranean. Another problem consists in ongoing development of the country, reflected in low investments into tourism, comparing to other European countries. Therefore, the main perspective for the tourism development in Estonia includes active redirection towards eco-style sustainable tourism: camping, biking, sea side recreation, construction of summer cottages for vacations, organized tours to Natural Parks. This paper, supported by fieldwork, has analytical character reviewing current Estonian tourism dynamics. Sociopolitical effects on current tourism directions are discussed, while modern touristic system in Estonia compared to Soviet. The overview of the recreation resort places was performed in Häädemeeste municipality, Pärnu district, and resulted in series of thematic author photos. The research was performed at the University of Tartu.
\end{abstract}

\section{Keywords: Baltic Sea region, tourism development, recreation, post-Soviet Estonia.}

\section{INTRODUCTION}

\subsection{Research aim}

The target aim of this research is analysis of the modern trend in the development of tourism on Baltic Sea coasts with a special case of Estonia. The research topic is focused on the context of tourism resorts in Estonia generally, and of coastal Baltic seaside resorts in Pärnu region specifically. Some important issues discussed include decline of Soviet epoch and restructuring of touristic cluster that happened during the new capitalist era. This also includes case study of Pärnu area, which was traditionally a popular resort place during Russian Empire in XIX century, during the Soviet time and still keeps this position now. The touristic development of the particular resort place like Pärnu is not necessarily associated with the overall socio-economic development of the country, or its particular political-historical phase, but is rather the outcome of complex interactions between natural, climatic and sociological factors, as well as external forces (development of touristic infrastructure and available services), and cultural-historical appreciation of the place (long tradition of Pärnu resort, distinctiveness of the place, sightseeing possibilities for public, etc).

The problem of tourism development is being currently widely discussed on the European level: various workshops, seminars, conferences, discussions and lectures are organized focusing on the tourism. Main problems highlighted and investigated concern inter-relationships of man and nature: impact of the tourism on the environment, effects of the environmental, socio-political and economic conditions on the tourism development and vice versa, the impact of the tourism on the sustainability of natural ecosystems. Overview of the discussed tendencies and current problems are summarized in the relevant numerous papers (e.g. Smeral, 2000; Jansson, 2001; Palang et al., 2011; Gossling, 2002; Kernel, 2005).

Estonia has its own specific characteristics in the tourism development, mostly caused by the political history. The end of the Soviet Union epoch since the 1990s caused great economical and sociopolitical reformation of the country. The disintegration of the USSR caused considerable changes in the socio-economic and political structure in many countries of Warsaw treaty from the post socialistic area, which naturally affected touristic cluster (Berg and Oras, 2000, Light and Dumbraveanu, 1999; Vanwambeke et al., 2012). Accordingly, in Estonia the system of land management, resource usage and urban development significantly changed in the past 20 years, which reflected overall socioeconomic and political situation in the country (Roose et al., 2012). Nowadays, the most typical processes in the coastal region of the country include suburbanization, intense construction of summer cottages (also known as "second summer houses") and creation of new, modern touristic places: hotels camping areas, hostels, etc.

\subsection{Research area}


The research region encompasses Baltic Sea coastal area south western part of Estonia. Spatial extent of the exact study area is limited to the surroundings of Pärnu County (Fig.1). The region of Pärnu is valuable environmental and recreational part of Estonia. Mild climate condition and precious coniferous forests dominating in this area make it a unique environmental part of Estonian nature. Landscapes of western Estonia are rich and world-known for their diversity, variability and unique composition structure. These include, for example, mixed and broadleaved forests, traditional agricultural semi-natural landscapes, wooded meadows, plant communities, heathland, bogs and moors, complex anthropogenic areas with different land use structure, shrubland, grasslands, birch-dominating coastal areas

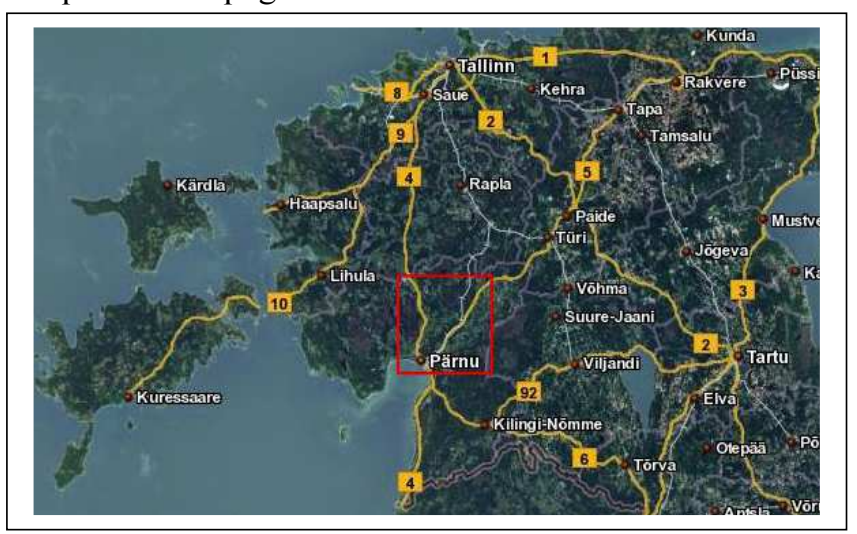
and flooded meadows (Zobel et al., 2012).

Such environmental and geographic characteristics of the region together with advantageous location on the coastal area of Pärnu Bay and excellent facilities for the tourism make this region traditionally popular as a tourism destination place (Ahas et al., 2008). Apart from the intense tourism in the study area, as it is mentioned above, the area of Pärnu county is also known for traditional agricultural activities (field crops cultivation, intensive planting, etc), as well as extensive housing development in the rural area. All these factors create additional pressure on the local ecosystems and may cause fragmentation of the landscape structure (Mander et al., 2010).

Figure 1. Study area: Pärnu surroundings, Estonia. Source: xgis.maaamet.ee, modified by authors.

Methodologically, current study was based on the analysis of the reports of the trends in current tourism development in Estonia, and on the in-situ observations of the resort places in the study area (Baltic coastal territories, Partnu surroundings, Fig.1), in order to analyze intensity of the local tourism development in the post-USSR time.

\section{GLOBALIZATION AS THE MODERN TREND OF THE TOURISM}

Globalization is a modern concept commonly used nowadays to explain variety of social, natural and economic processes. Globalization can be described as a movement in the direction of increasing world economic integration through the reduction of natural and human-made barriers to exchange and increased international flows of capital and labor (Aramberri, 2009). Globalization affects many aspects of the functioning of the society, and as a consequence, tourism as well, since it is an integral part of the modern social development. Currently, the tourism reached a high level of globalization in its development. The new tendency towards integration and globalization of tourism became popular in the world society in late XX-century.

The advantages of the globalization in tourism for the society consists in deep interconnection of tourist flows with various country destinations, even those not very popular earlier due to the limited natural access or climatic conditions. Other benefit of globalization is increasing world trade development, growth of various divisions of labor, internationalization of production of food, goods, hotel management system and touristic services, rapid and fast exchanges of information, computerization, standardization of guide touristic tours, etc. However, the globalization implies also a problem of maintaining the planet in global sense and tourist resort places in regional and local sense in a sustainable and nondestructive way, so that the tourism should not bring negative consequences on the surrounding landscapes and natural ecosystems. Various reports focusing on this problem have been written in this context (Ko, 2005; Klein-Vielhauer, 2009; Hong et al., 2003; Kozak and Martin, 2012; Lee, 2001).

The crucial point of the globalization is that by its highest development there will still be a place for regional development as a concurrent and opposite trend. Hence, the natural geographical borders that arise when people move to the vacations will always exist. However, globalization progressively diminish and resolve potential and real borders and barriers, makes tourists and countries dependent on each other and interconnected. In Baltic post-Soviet countries like Estonia the globalization of tourism is now evident new and rapidly developing direction for the touristic industry.

\section{Current Local TOURISM DEVELOPMENT IN POST-SOVIET COUNTRIES}

Despite evident and overall trend in globalization of the tourism, there are regional and local specific nuances typical and characteristic for each country. Thus, in Estonia and other post-USSR countries, the tourism, leisure, traveling and tourism-related industry received new dimensions, rapid development and directions. Many research papers have been reported (e.g., Wight and Lennon, 2007; Kapaciauskaite, 2011; Upchurch and Teivane, 2000) with focus on post-Soviet tourism development in new independent countries, as well as regional and local problems associated with global economic and social changes in these countries.

In general, the traveling moving tourist masses are not easily go beyond their national borders or, at least, further than the EU and Mediterranean. Even the most remote destinations are still encircled by Eurasia continent, and only few persons go to Australia, southern Africa or the Americas. It should be noticed also that this group includes also travel flights made by businessmen who have duties in Europe, the U.S. and Canada and Austral-Asia. The most important factor for choosing a place destination while going to vacations is individual factor and family traditions. Thus, as 
noticed by Daugstad (2007), personal views may differ according to age, generation, gender, place of residence, ties to urban or rural areas, etc. However, as reported in an investigation on Estonian tourism spatial locations performed by detection of mobile phone locations (Ahas et al., 2008), the majority of Estonians prefer national holidays vacations with some temporal seasonality variances: coastal areas are much more popular during summer tourism season, while continental inland areas are mostly being visited during the winter.

Among other nations traditionally often visiting Estonia are Russians and Finnish. Finnish tourists traditionally visit western Estonia (Baltic Sea coasts), while Russians preferably concentrate on the Estonian-Russian border, in eastern Estonia, on the Finnish Gulf. These two nations are notably the most representing tourists, while others visit Estonia significantly lesser. Hence, there are also some Latvians who made up a higher percentage in Saaremaa and Pärnu region during summer and in Otepaa and Lake Peipsi in winter (Ahas et al., 2007). The non-popularity of Estonia among other nations, comparing to touristic giants, like France or Spain, can be explained by various factors. First of all, it is specific climatic conditions of the territory with rather cool summers and cold waters in Baltic Sea even during summer months. Unpleasantly cold winters and lack of world-known sightseeings of UNESCO level heritage increase this aspect. Another factors consists in long Soviet history of the country, which results in bad service facilities and under-developed touristic cluster (though currently in process of gradual growth and development). It also includes still insufficient quantity of world-level hotels, possibilities for recreation and spa-centers (e.g. comparing to Finland).

Another factor which plays role in the positive development of tourism in modern Estonia is the independency of the country from the USSR. As reported in study (Gil-Pareja et al., 2007) of impact that have embassies and consulates on the touristic inflow, it has been proved that they play a positive role in attraction of potential tourists to the country. Thus, after Estonia became an independent country, the information about Estonian resort places, including brochures and maps, is available and freely distributed. This welcomes future tourists and facilitates planning a journey, which became more easy comparing to the Soviet times when certain restrictions of entrance to the USSR did exist.

Currently, it is estimated (Worthington, 2003) that about 90,000 foreign tourists a year visit Pärnu, of which about 50,000 are Finns, followed by 7,200 Swedes, 4,500 Russians, 2,700 Americans, and approximately 17,100 of other nationalities.

\subsection{Modern development in Estonian tourism: eco-friendly hotels and appreciation of the environment}

In general, Estonian touristic sector currently transforms a gradual functional shift away from authoritative style of tourism with common Soviet guesthouses towards capitalist privately held small hotels. Nowadays, some of former hotels naturally become a bankrupts or else depopulated and lost their tourism function completely. However, as justly recommended by Agarwal (2002), such decline may be avoided in case the counter-measures are accepted and used, such as re-orientation of the hotels towards environmental eco-friendly style, enhancement of the attractions for kids and sightseeings for adults, or even the repositioning of the destination within an overall touristic market.

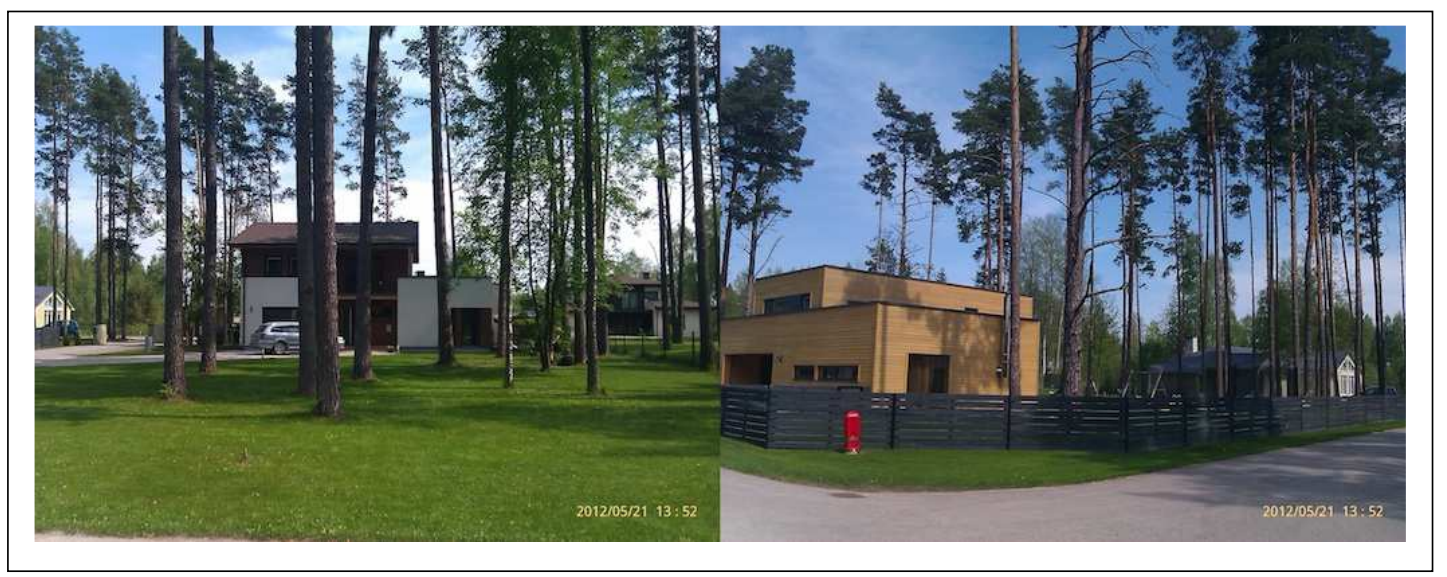

Figure 2. Example of rural environmental tourism: eco-style new cottages built since 1990s in Pärnu surroundings. Photo: author.

One of the re-orientation principles of the modern tourism includes intensive development of the eco-friendly, environmentally oriented touristic resorts, or, in other words, eco-style rural tourism. Though less evident in the large cities and their suburbia, e.g. in Tallinn, eco-tourism has turned into a highly popular tendency for coastal small towns and resorts. The eco-style resorts development is currently a highly developed line in neighboring Finland, which traditionally gives following examples for Estonia. Eco-styles tourism includes not only constriction of ecologically styled buildings and hotels but also a maintenance of the surrounding landscapes, so that the houses are harmonically drawn into the natural landscape without neither esthetic nor physical disturbance and misbalance (Fig.2).

Important trend in the development of tourism in Estonia is intensification of rural tourism. Like in other Baltic, mostly agrarian, post-Soviet countries, rural, environmentally friendly tourism is an efficient mean for further tourism development. It has evident advantages both for nature and society, thus enabling balanced co-existence of the man and environment. First, development of ecological (or, eco-style) tourism and recreation activities assists in conservation of natural and cultural heritage objects, buildings, landscapes, traditions, and customs (Balezentis et al., 2012). These resources, in turn, directly affect the quality of the region, the overall appreciation of this particular place by the tourists. 
In view of global popularization of the ecology, environment and natural landscapes, people tend to select most "natural" places for vacation or as tourism destinations in order to live in right environment.

Another, though may be less evident advantage of ecological tourism consists in economic support of the local infrastructure and social functioning. Namely, popularization of the places for ecological and rural tourism creates jobs opportunities for the active local population, who may receive additional income due to the increased tourist inflow.

Finally, ecological tourism is a sustainable activity which serves as a basis for conservation of sustainable and renewable natural resources, e.g. forests, landscapes, etc. Eco-style tourism depends on a wide range of natural and cultural resources, infrastructure, and service facilities, as well as provision of accommodation, food, beverages, and goods (Cawley and Gillmor, 2008). Therefore, for environmentally-friendly, proper regulation and functioning of tourism cluster, the development of the tourism should be in sustainable way, i.e. not affect local ecology and cause negative impacts on the quality of the natural environment, landscapes, social infrastructure and cultural sightseeings.

\subsection{Tourism tradition in Pärnu: maintaining history in the present}

The history of Pärnu resort goes back to the XIX century, when Estonia was under protection of Russian Empire. Domestic tourism in the Baltic Provinces including Pärnu, was largely connected with sea bathing during July month. The season always ended by August 1 due to the restricted climatic conditions (Kohl, 1842). During the First World War the development of the resort was largely restricted, though quickly revived after the war. In 1920s the Rannapark has been restored, and a new mud bath constructed, opened for tourists. In late 1920s - 1930s Estonian hotels and restaurants were one of the cheapest touristic destinations in Baltic Europe, which was advertised in the tourist literature of that time. The easy access to the Pärnu region was facilitated by good railway communication with Germany, Latvia, and Lithuania. As a consequence, this region was widely visited by various international guests with the majority of Scandinavians (e.g. Swedes, Finns), Poles, Germans and Brits (Worthington, 2003).

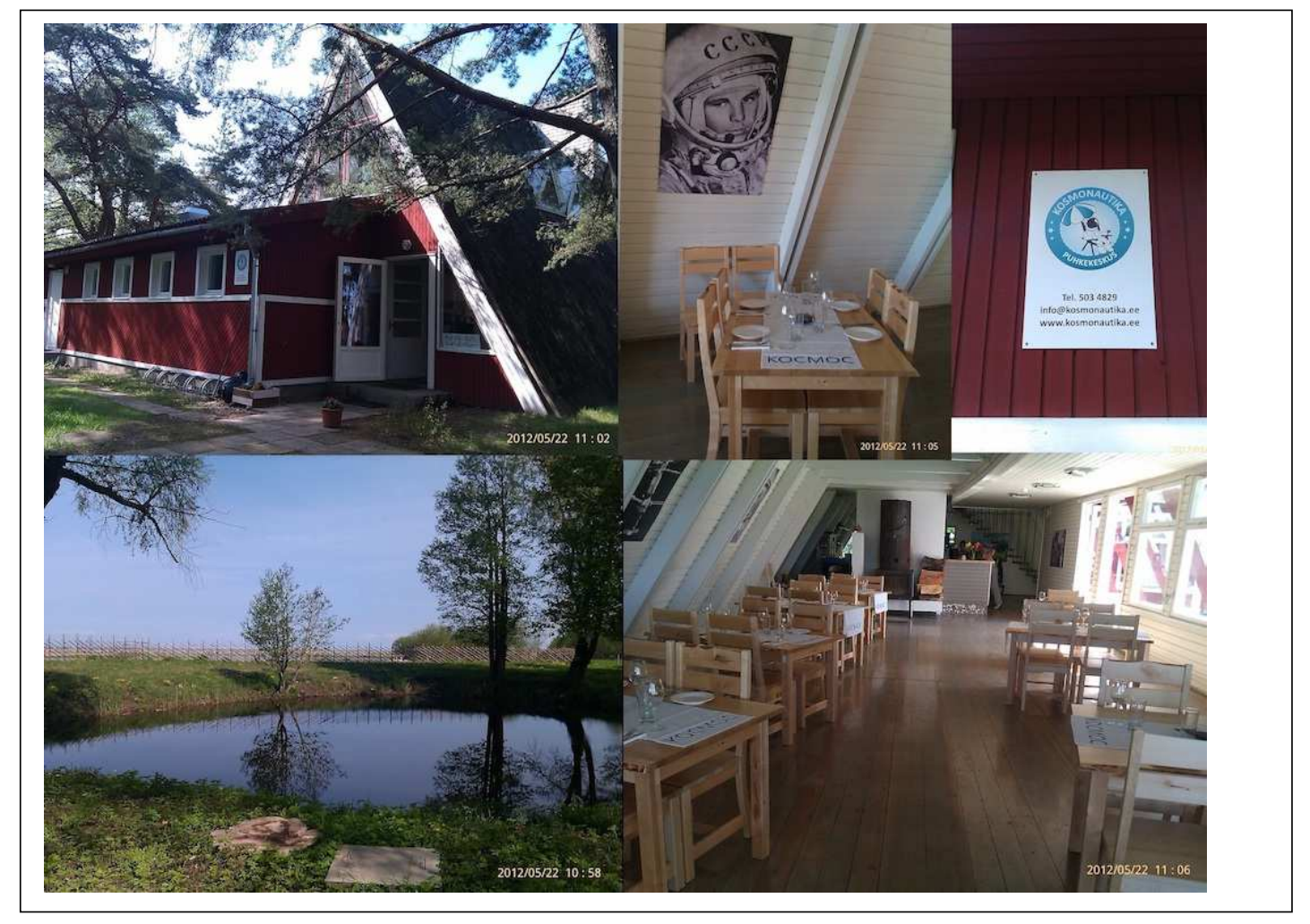

Figure 3. Interior and the surroundings of the Cosmonauts Hotel - a former Soviet summer resort for workers of space industry (www.kosmonautika.ee): applying space topic and cosmos theme in hotel: soviet cosmonaut Y.Gagarin who was the guest in this hotel. Photo: author.

During the totalitarian era of Soviet Union the tourism industry in east Baltic Sea region has been diminished, since the primary goal of the state was industrial usefulness and functionality, with negative reaction towards private ownership. Evidently, the business of private hotels and restaurants has been diminished drastically. The existing touristic entrepreneurs were reconstructed to the state-controlled "Existing organizations were amalgamated into the All Union Voluntary Society for Proletarian Tourism and Excursions" (Worthington, 2003), with all touristic initiatives imperatively controlled and dictated.

Development of tourism under USSR epoch has brought many new directions to this social sector. Among negative features of Soviet era were restrictions upon foreign tourism in Pärnu region, and poor management in the Soviet planned economy which reflected in bad service facilities and underdeveloped hotelier tradition. However, there were some positive consequences of this reconstruction as well: the coasts and beaches in Pärnu region were protected as "public health zone" designed for recreation, where only selected activities were permitted and vehicles were 
prohibited. The most precious parts and areas of the Baltic Sea were served as special places for high political leaders who took their summer vacations here, as well as for the employees from the strategic industrial sectors: spacecraft and cosmos exploration. These hotels, former restricted for politicians, prominent scientists, artists and cosmonauts, are currently being reconstructed and re-opened for public tourists (Fig.3).

Regaining the independency of Estonia has revolutionized Baltic tourism. Consequently, the modern, "westernlooking" and quickly constructed hotels were created and the new, revitalized era for tourism industry in Estonia started, mostly based on privatization and foreign investments (from Finland or Germany).

\subsection{Development of private sector and intensive building of summer cottages}

The development of local-scale tourism can be of special benefit for Estonia, whose resources traditionally include small towns and villages, often of architectural interest, which are ideal for the development of tourism-related cultural and recreational services. Important way of tourism development in modern Estonia is family businesses, which often implies direct host-guest interactions in the family-runed hotel or hostel (Getz and Carlsen, 2005). The personal relationship and friendship are often vital to guest experiences of the tourist, his or her satisfaction, which naturally makes a place popular and thus, contributes to further tourism development in the community.

Expanding the touristic dimensions is highly profitable for the country due to the evident income of financial flows. However, as reported by Endo (2005), the overwhelming majority of foreign direct investments is so far directed to the developed countries, like France, the UK, the Netherlands, Spain, and soon. For some developing countries and for the countries that are in transitional economic situation, like Estonia after the fall of the USSR, the role played by foreign tourist investments in touristic industry is incomparable lesser in their overall economic activities.

Currently, Estonia has intensive privatization process, which is caused by serious changes in state regulations on property and ownership. Naturally it caused intensification of construction of privately hold hotels and summer cottages, built both for personal (family based) needs for spending summer vacations, and for rent to incoming tourists, domestic and international. Land management system and urban development of Estonia significantly changed in the past 20 years, which reflects overall socio-economic and political situation in the country (Roose et al. 2012). Nowadays, suburbanization and development of second houses become the major and most evident processes in the current urban dynamics of modern Estonia (Palang and Peil, 2010).

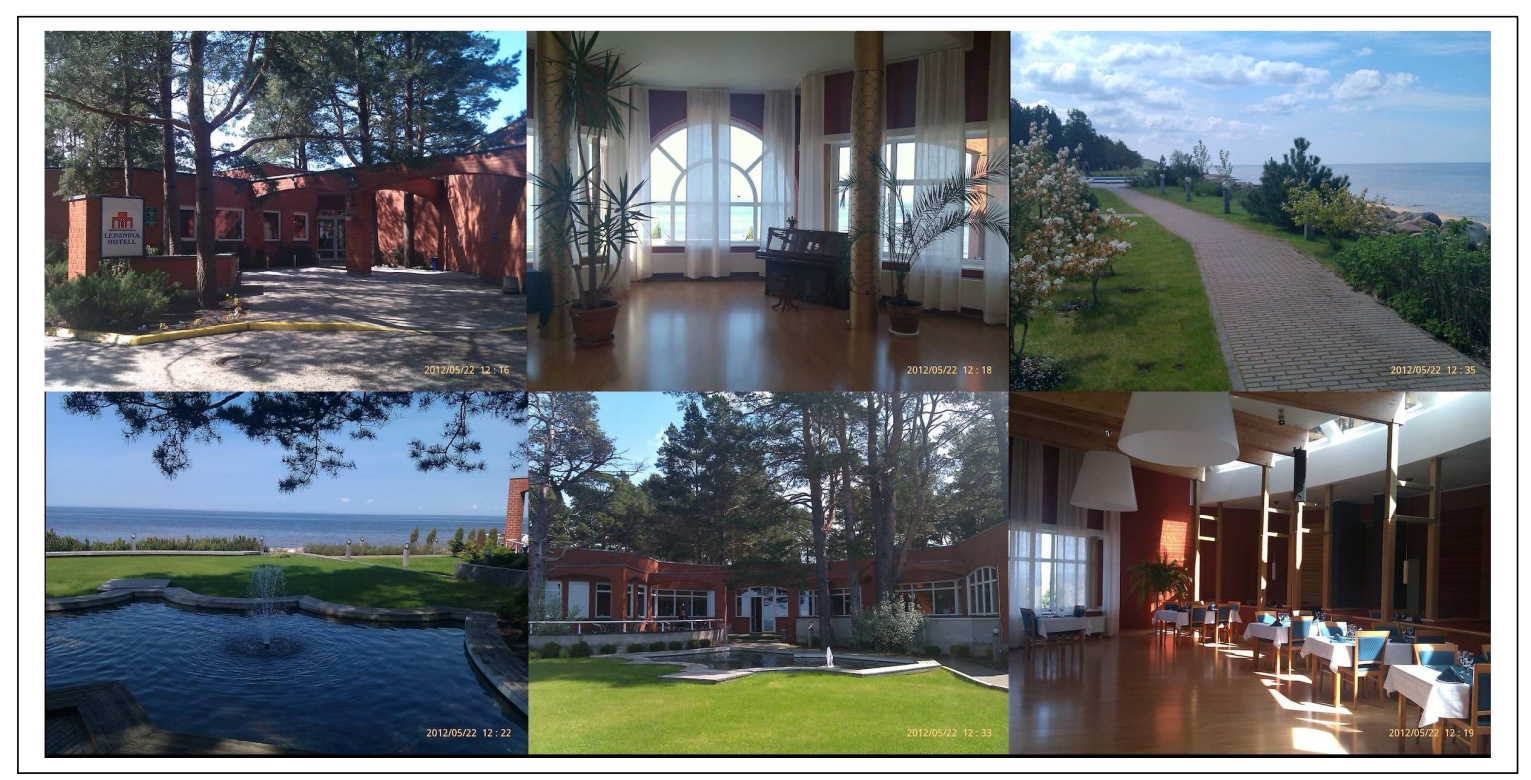

Figure 4. Example of private Estonian spa hotel (Lepanina Hotell) created on the Baltic Sea coast: a successful combination of modern European hotel design, location in the nearest proximity of the sea, maritime design landscapes, and coniferous forests makes it a valuable health resort area. Photos: author.

There are multifold processes explaining this phenomena. The main triggering factor is caused by ground serious changes in the public law and ownership system of the country, which enabled to expand ownership to the immobility objects (which was largely restricted and controlled by the state during the USSR epoch). Implementation of new land reform with modest regulation of land use activated touristic and housing market in Estonia, enabled privatization, home ownership, restitution of suburban land (Hess et al., 2011). Together with accessible mortgage system developed in Estonia since 2000s, it facilitated purchase of private houses for large number of people from upper middle class, which accelerated suburban residential development. This has naturally activated privatization of real estate objects and increased size of private property and privately hold hotels (Fig.4).

Another factor has economic character and includes development of the market economy and overall socio-economic 
growth in Estonia, which caused positive changes in economic sphere of the population of the country. Hence, new capitalistic, market based economy implemented in Estonia after the fall of USSR, caused gradual positive social changes: personal economic growth, well-being, new style of life, increased number of private cars, and in general, growing size of the middle class society. These factors triggered intensive construction of touristic hostels and guesthouses, private hotels, as well as second houses and summer cottages in recreation zones where families live during vacations (these homes are sometimes also referred as "dachas"). These factors, both of economic and juridic characters, have direct and positive impact on the touristic cluster of country. As a consequence, since independency of Estonia, the touristic sector changed significantly towards intensification, revitalization and overall improvements in the tourism and leisure industry.

The development of tourism and overall economic growth in various developed countries have evident correlation and relationship though not necessarily linear (Po and Huang, 2008), since the traveling and going to resort places can only be maintained by sufficient resources. Nowadays, the development of tourism over the world leads to the strategy of cultivating an entrepreneurship and own touristic business environment. The same way of the development is now open for Estonia and other post-Soviet countries. Besides, as noticed by Getz and Petersen (2005), strategy of own touristic business brings advantages for the regional economy, as it requires creation of new working places which in turns brings evident advantages for the economy of the region. Privately oriented touristic business is also profitable for optimization of tourism competitiveness in the country, because the profit and growth-oriented owner (landlord or landlady) will invest products and marketing initiatives, rather than it was in USSR times in old types of guesthouses and Soviet hotels, which were mostly controlled by the state within a given business type and size.

\section{CONCLUSION}

Current research provided balanced insight into the investigations of complex processes connected to the tourism cluster development in the Estonian western region: socio-economic development, post-socialistic heritage, environmental and cultural processes. It furthermore assists to the development of sustainable appropriate future actions in touristic industry of this specific region. The paper has analytical character, and contributes to assist in further development of touristic industry in Baltic Sea area. Hence, may be used for local land and recreation management.

Presented work illustrated application of complex methods combining analytical review of the tourism development in Pärnu region with a case study of Häädemeeste municipality, and in-situ observations of touristic activities in the study area. Methodology is based on study of relevant numerous literature, statistical facts, and performed fieldwork excursions. The fieldwork monitoring and observations were aimed at studies of touristic possibilities in various selected landscapes of eastern region of Baltic Sea. The environmental aim of this paper is contribution towards landscape monitoring for sustainable development of Baltic Sea area and co-existing of man and nature. The work is aimed to demonstrate how tourism sector is successfully developing in the conditions of post-Soviet socio-economic recovering and specific climatic conditions.

Furthermore, study analyzed trends and general directions for the future of tourism in post-Soviet Estonia, with focus on changes that affect this region in view of the process of globalization. Although the study is focused primarily on an Estonian context, it has wider implications for the analysis of tourism development and management of other countries with similar transitional socio-economic phase which have the same problems in tourism development: e.g. post-Soviet countries or Eastern European region, newly integrated into the EU.

That being said, it should be also highlighted that our knowledge of the real dimensions and perspectives, potential and tendencies of tourism and travel in the post-USSR region is still underestimated. The human potential and resources of the population from the post-Soviet countries have great potential for the development of tourism both in Baltic Sea area and in other regions of the world.

\section{ACKNOWLEDGMENT}

The financial support of this research has been provided by the DoRa Scholarship Committee of the European Social Fund (ESF). The technical support of the fieldwork was performed with kind assistance of Mrs. Irja Pede, employee from the Häädemeeste municipality, and Mrs. Merle Looring, a lecturer of the University of Tartu, Pärnu College, Department of Ecosystem Management, during the organized fieldwork company in Pärnu County.

\section{REFERENCES}

[1] Agarwal, S. 2002. Restructuring seaside tourism. Annals of Tourism Research, 29 (1), 25-55, Elsevier Science.

[2] Ahas, R., Aasa, A., Mark, U., Pae, T., and Kull, A. 2007. Seasonal tourism spaces in Estonia: Case study with mobile positioning data. Tourism Management 28, 898-910.

[3] Ahas, R., Aasa, A., Roose, A., Mark, U., and Silm, S. 2008. Evaluating passive mobile positioning data for tourism surveys: An Estonian case study. Tourism Management 29, 469-486.

[4] Aramberri, J. 2009. The future of tourism and globalization: Some critical remarks. Futures 41, 367-376.

[5] Balezentis, T., Krisciukaitiene, I., Balezentis, A., and Garland, R. 2012. Rural tourism development in Lithuania (2003-2010) - A quantitative analysis. Tourism Management Perspectives 2-3, 1-6.

[6] Berg, E., and Oras, S. 2000. Writing post-Soviet Estonia on to the world map. Political Geography 19, 601-625.

[7] Cawley, M., and Gillmor, D.A. 2008. Integrated rural tourism: concepts and practice. Annals of Tourism Research, 35 (2), $316-$ 
337.

[8] Daugstad, K. 2008. Negotiating landscape in rural tourism. Annals of Tourism Research, 35 (2), $402-426$.

[9] Endo, K. 2006. Foreign direct investment in tourism - flows and volumes. Tourism Management 27, 600-614.

[10] Getz, D., and Carlsen, J. 2005. Family business in tourism: state of the art. Annals of Tourism Research, 32 (1), $237-258$.

[11] Getz, D., Petersen, T. 2005. Growth and profit-oriented entrepreneurship among family business owners in the tourism and hospitality industry. Hospitality Management 24, 219-242.

[12] Gil-Pareja, S., Llorca-Vivero, R., Martinez-Serrano, J.-A. 2007. The impact of embassies and consulates on tourism. Tourism Management 28, 355-360.

[13] Gossling, S. 2002. Global environmental consequences of tourism. Global Environmental Change 12, $283-302$.

[14] Hess D.B., Tammaru T., Leetmaa K. 2011. Ethnic differences in housing in post-Soviet Tartu, Estonia. J. Cities, doi:10.1016/ j.cities.2011.10.005

[15] Hong, S., Kim, J., Kim, S., 2003. Implications of potential green tourism. Annals of Tourism Research, 30 (2), $323-341$.

[16] Jansson, B.O., Stalvant, C.E. 2001. The Baltic Basin Case Study - towards a sustainable Baltic Europe. Continental Shelf Research 21, 1999-2019.

[17] Palang, H., Alumäe, H., Printsmann, A., Rehema, M., Sepp, K., Sooväli-Sepping, H. 2011. Social landscape: Ten years of planning 'valuable landscapes' in Estonia. Land Use Policy 28, 19-25.

[18] Kapaciauskaite, I. 2011. Environmental governance in the Baltic Sea Region and the role of non-governmental actors. Procedia Social and Behavioral Sciences 14, 90-100.

[19] Kernel, P. 2005. Creating and implementing a model for sustainable development in tourism enterprises. Journal of Cleaner Production 13, 151-164.

[20] Klein-Vielhauer, S. 2009. Framework model to assess leisure and tourism sustainability. Journal of Cleaner Production 17, 447454.

[21] Ko, T.G. 2005. Development of a tourism sustainability assessment procedure: a conceptual approach. Tourism Management 26, 431-445

[22] Kohl, J. 1842 Russia-St. Petersburg, Moscow, Kharkhoff, Riga, Odessa, the Germany. Provinces on the Baltic, the Steppes, the Crimea, and the Interior of the Empire. Translated and abridged from the German. London: Chapman and Hall.

[23] Kozak, M., Martin, D. 2012. Tourism life cycle and sustainability analysis: Profit-focused strategies for mature destinations. Tourism Management 33, 188-194.

[24] Lee, K.F. 2001. Sustainable tourism destinations: the importance of cleaner production. Journal of Cleaner Production 9, 313323.

[25] Light, D., and Dumbraveanu, D. 1999. Romanian tourism in the post-Communism period. Annals of Tourism Research, Vol.26, No.4., 898-927.

[26] Mander, U., Uuemaa, E., Roosaare, J., Aunap, R., Antrop, M. 2010. Coherence and fragmentation of landscape patterns as characterized by correlograms: A case study of Estonia. Landscape and Urban Planning 94, 31-37.

[27] Palang H, Peil T 2010. Mapping future through the study of the past and present: Estonian suburbia. Futures 42, 700-710

[28] Po, W.-C., Huang, B.-N. 2008. Tourism development and economic growth - a nonlinear approach. Physica A 387, $5535-5542$.

[29] Roose, A., Kull, A., Gauk, M., Tali, T. 2012. Land use policy shocks in the post-communist urban fringe: A case study of Estonia. Land Use Policy 30, 76-83.

[30] Smeral, E., Weber, A. 2000. Forecasting international tourism trends to 2010. Annals of Tourism Research, 27 (4)., $982-1006$.

[31] Upchurch, R.S., and Teivane, U. 2000. Resident perceptions of tourism development in Riga, Latvia. Tourism Management 21, 499-507.

[32] Vanwambeke, S.O., Meyfroidt, P., Nikodemus, O. 2012. From USSR to EU: 20 years of rural landscape changes in Vidzeme, Latvia. Landscape and Urban Planning 105, 241-249.

[33] Wight, A.C., Lennon, J.J. 2007. Selective interpretation and eclectic human heritage in Lithuania. Tourism Management 28, $519-529$.

[34] Worthington, B. 2003. Change in an Estonian resort. Contrasting development contexts. Annals of Tourism Research, 30 (2), 369-385.

[35] Zobel, M., Pärtel, M., Zobel, K., Püssa, K., Kalamees, R., Helm, A. Liira, J. 2012. Vegetation patterns and their underlying processes. In: 56th Annual Symposium of the International Association for Vegetation Science. 